Article

\title{
Application of Trichoderma harzianum, 6-Pentyl- $\alpha$-pyrone and Plant Biopolymer Formulations Modulate Plant Metabolism and Fruit Quality of Plum Tomatoes
}

\author{
Petronia Carillo ${ }^{1}$, , Sheridan L. Woo ${ }^{2,3,4, *}$, , Ernesto Comite ${ }^{5}$, Christophe El-Nakhel ${ }^{5}{ }^{\circ}$, \\ Youssef Rouphael ${ }^{5} \odot$, Giovanna Marta Fusco ${ }^{1}$, Assunta Borzacchiello ${ }^{6}$, Stefania Lanzuise ${ }^{5}$ and \\ Francesco Vinale ${ }^{4,7}$ (D) \\ 1 Department of Environmental, Biological and Pharmaceutical Sciences and Technologies, University of \\ Campania “Luigi Vanvitelli”, Via Vivaldi 43, 81100 Caserta, Italy; petronia.carillo@unicampania.it (P.C.); \\ giovannamarta.fusco@unicampania.it (G.M.F.) \\ 2 Department of Pharmacy, University of Naples Federico II, 80131 Naples, Italy \\ 3 Task Force on Microbiome Studies, University of Naples Federico II, 80055 Portici, Italy \\ 4 National Research Council, Institute for Sustainable Plant Protection, 80055 Portici, Italy; frvinale@unina.it \\ 5 Department of Agricultural Sciences, University of Naples Federico II, 80055 Portici, Italy; \\ ernesto.comite@unina.it (E.C.); Nakhel_Christophe@hotmail.com (C.E.-N.); \\ youssef.rouphael@unina.it (Y.R.); stefania.lanzuise@unina.it (S.L.) \\ 6 National Research Council, Institute for Composite Polymers and Biomaterials, 80125 Napoli, Italy; \\ assunta.borzacchiello@cnr.it \\ 7 Department of Veterinary Medicine and Animal Productions, University of Naples Federico II, \\ 80137 Naples, Italy \\ * Correspondence: woo@unina.it
}

Received: 23 May 2020; Accepted: 17 June 2020; Published: 19 June 2020

\begin{abstract}
Many Trichoderma are successfully used to improve agriculture productivity due to their capacity for biocontrol and to stimulate plant growth and tolerance to abiotic stress. This research elucidates the effect of applications with Trichoderma harzianum strain T22 (T22), or biopolymer (BP) alone or in combination (BP + T22 or BP + 6-pentyl- $\alpha$-pyrone (6PP); a Trichoderma secondary metabolite) on the crop performance, nutritional and functional quality of greenhouse tomato (Solanum lycopersicum L. cultivar Pixel). T22 elicited significant increases in total yield (+40.1\%) compared to untreated tomato. The content of lycopene, an important antioxidant compound in tomatoes, significantly increased upon treatment with T22 (+49\%), BP + T22 (+ 40\%) and BP + 6PP $(+52 \%)$ compared to the control. T22 treatments significantly increased the content of asparagine $(+37 \%)$, GABA $(+87 \%)$ and MEA $(+102 \%)$ over the control; whereas BP alone strongly increased GABA $(+105 \%)$ and MEA $(+85 \%)$. The synthesis of these compounds implies that tomato plants are able to reuse the photorespiratory amino acids and ammonium for producing useful metabolites and reduce the pressure of photorespiration on plant metabolism, thus optimizing photosynthesis and growth. Finally, these metabolites exert many beneficial effects for human health, thus enhancing the premium quality of plum tomatoes.
\end{abstract}

Keywords: microbial biostimulant; non-microbial biostimulant; carboxymethyl cellulose; Pluronic F-127; amino acids; lycopene; GABA; Solanum lycopersicum L. 


\section{Introduction}

Until a few decades ago, agriculture intensification was the principal strategy proposed to ensure food security and socio-economic development, guaranteeing continuous productivity from season to season, in optimal and sub-optimal conditions [1]. However, at present, it is clear that to feed the growing global population, expected to reach 10 billion people in 2050, it is necessary not only to reconcile an increased need for agricultural productivity, but to also resolve the extensive use of chemical products (i.e., fertilizers and pesticides) and their negative impact on the environment and human health [1,2]. According to the FAO [3], this objective can only be achieved by being attentive to nutritional and consumption choices and by employing sustainable agricultural management practices. A promising and eco-friendly strategy for agriculture could be the integrated use of diverse non-chemical methods and products in cropping systems, which includes the implementation of plant biostimulants (PBs), based on beneficial microorganisms and molecules of natural origin [4]. PBs include various bioactive substances, formulations of compounds or microorganisms, such as humic and fulvic acids, macro and microalgal extracts, protein hydrolysates, chitosans and silicon, as well as mycorrhizal fungi and plant growth-promoting microorganisms able to improve plant growth, vigor and yield even under suboptimal conditions [5,6]. Other plant beneficial microorganisms, in particular Trichoderma spp., are able to control pathogens and pests $[7,8]$, as well as to increase plant nutrient use efficiency (NUE) [9], synchronize the up-regulation of photosynthetic capacity and carbohydrate metabolism [10,11], plus improve plant growth, yield and produce quality [12-14]. In particular, Trichoderma asperellum, Trichoderma atroviride, Trichoderma harzianum, Trichoderma virens and Trichoderma viride have been demonstrated to act as plant biostimulants, attributed to their capacity to stimulate NUE, and consequently increase plant vigor and tolerance to abiotic stresses $[9,12,13,15,16]$. It is important to specify that NUE does not only depend upon nutrient uptake by the plant, in particular of nitrogen, but it is also affected by the nutrient assimilation of organic compounds, as well as their translocation throughout the plant $[17,18]$. The beneficial activity of fungi belonging to Trichoderma depends upon their ability to establish a molecular dialogue with the plant, by actively secreting and exchanging small molecules (i.e., hormone-like compounds), able to re-modulate gene expression and metabolic processes in plant roots and shoots $[19,20]$. Some bioactive metabolites can directly increase elemental (i.e., $\mathrm{Ca}, \mathrm{Fe}, \mathrm{K}, \mathrm{Mg}$, Mn, $\mathrm{P}$ and $\mathrm{Zn}$ ) uptake in the roots [21-23]. However, these metabolites are also responsible for the direct stimulation of root growth and development, thus enhancing the surface area and root extension in the soil environment, which improves NUE [11,24,25], by using mechanisms similar to those of other beneficial microbes in the root community (i.e., arbuscular mycorrhiza and plant growth-promoting rhizobacteria) [26-28].

Trichoderma harzianum T-22 is able to colonize the roots of most plant species independently of the soil type [14,29]. Many Trichoderma are good producers of a variety of secondary metabolites, some which demonstrate antibiotic proprieties and plant growth effects. A well-studied volatile compound, 6-pentyl- $\alpha$-pyrone (6PP), responsible for the coconut-like odor of Trichoderma cultures [30], has demonstrated moderate antibiotic activity in vitro and in vivo against several phytopathogens [7,31,32], but interestingly, when used in combination with fungus cell wall degrading enzymes, synergistic effects were noted in the inhibition of the target fungal pathogens by $60 \%[7,10]$. In addition, when $6 \mathrm{PP}$ was applied exogenously at very low concentrations (e.g., by $1 \mathrm{ppm}$ root applications or $1 \mu \mathrm{M}$ shoot spray), to wheat or tomato seedlings and etiolated pea stems, as well as to substrates with canola or tomato seeds, an auxin-like effect was observed in plant growth and development [33].

The possibility to obtain new biostimulant preparations that optimize the application of beneficial microorganisms, or the controlled release of their bioactive metabolites, could represent an innovative approach for eco-sustainable agriculture. To this end, the use of natural and/or synthetic biopolymer materials could be considered as carriers for Trichoderma and plant growth-promoting products to facilitate the formulation, delivery and activity of these active compounds [34,35], plus overcome the instability of the Trichoderma spore suspensions or the metabolite in water solutions. For the design of biopolymer formulations, it is very common to use carbohydrate polymers that present advantages, 
such as biocompatibility and biodegradability, and possess a high capacity to absorb water plus the possibility to load up a great variety of nutrients and agricultural compounds in their structure [36]. Among the polysaccharides, carboxymethyl cellulose (CMC), a polyanion derivative of cellulose commonly used as thickener and emulsifier, is widely utilized as a nutrient carrier and soil conditioner in agriculture. $\mathrm{CMC}$ reduces the surface tension of its solutions, improving the spreadability of the biopolymer formulations, in particular when Pluronic F-127 (PF-127) is added. Pluronics are triblock copolymers of polyoxyethylene (PEO; hydrophilic), and polyoxypropylene (PPO; hydrophobic), with the structure (PEO)a(PPO)b(PEO)a, which confers amphiphilic properties to the polymers. These formulations are widely used, due to their non-toxicity in the biomedical field, plus they have been tested in the agricultural context as a stabilizing agent in nanostructured systems for the controlled release of agrochemicals [37]. Many agricultural applications often require the presence of surfactants in order to improve the spreadability or dispersion of the formulations on hydrophobic plant surfaces (i.e., leaves, seeds or roots), a property that a CMC preparation could potentially provide. Furthermore, cellulose derivatives, such as CMC, exhibit the intrinsic advantages of cellulose: natural abundance, biodegradability and biocompatibility, combined with water solubility; all properties that integrate well with the concept of a green circular economy in agriculture.

This study aims to evaluate the effect of different biological treatments on the quantitative parameters associated with yield and the qualitative characteristics, as determined by analysis of metabolomic profiles, of mini plum tomato. The tested constituents included T. harzianum T22 and a biopolymer, consisting of carboxymethyl cellulose and a nonionic synthetic surfactant, that were applied singly or in combination to the plants. In addition, the effect of the bioactive Trichoderma secondary metabolite 6PP was also evaluated in combination with this biopolymer

This investigation will be useful in determining the outcome of combining the Trichoderma living fungus or a Trichoderma secondary metabolite with a biopolymer of vegetal origin in a biostimulant formulation that could have promising results for improving the yield components and nutritive characteristics of an important greenhouse horticultural crop, such as tomato.

\section{Results}

\subsection{Yield, Yield Components, Shape Index and Juice Quality}

The results indicated effects of Trichoderma, metabolite and biopolymer (BP) applications on crop productivity, whereby inoculations with Trichoderma harzianum strain T22 elicited a significant increase in fruit yield (by $40.1 \%$ ) in comparison to the untreated control (Figure 1), and a greater increase of $79.3 \%$ over the BP treatment alone. However, the beneficial effects of the Trichoderma, fungus or metabolite on yield parameters were not apparent in any of the combined $\mathrm{BP}+\mathrm{T} 22$ or $\mathrm{BP}+6 \mathrm{PP}$ treatments inoculated to the tomato plants, which were not significantly different from the control (Figure 1). Interestingly, the higher production observed in greenhouse tomato plants inoculated with T22 was attributed to both an increase in the mean fruit weight, and to a lesser extent, to a higher number of fruit produced per plant (Figure 1).

No significant differences among treatments were recorded for the fruit dry matter content (avg. 7.9\%), total soluble solids (TSS) (avg. $6.7^{\circ}$ Brix) and juice $\mathrm{pH}$ (avg. 4.4), whereas the shape index (SI) and juice electrical conductivity (EC) were significantly affected by the Trichoderma, metabolite or $\mathrm{BP}$ applications (Table 1). The SI and juice EC ranged from 0.77 to 0.81 and from 3.5 to $4.4 . \mathrm{dS} \mathrm{m}^{-1}$, respectively, with the lowest values recorded in BP +6 PP treatments (Table 1). Higher juice EC values are usually correlated with higher total soluble solids and organic acids, parameters determining the taste properties of tomato [38]. 
(A)

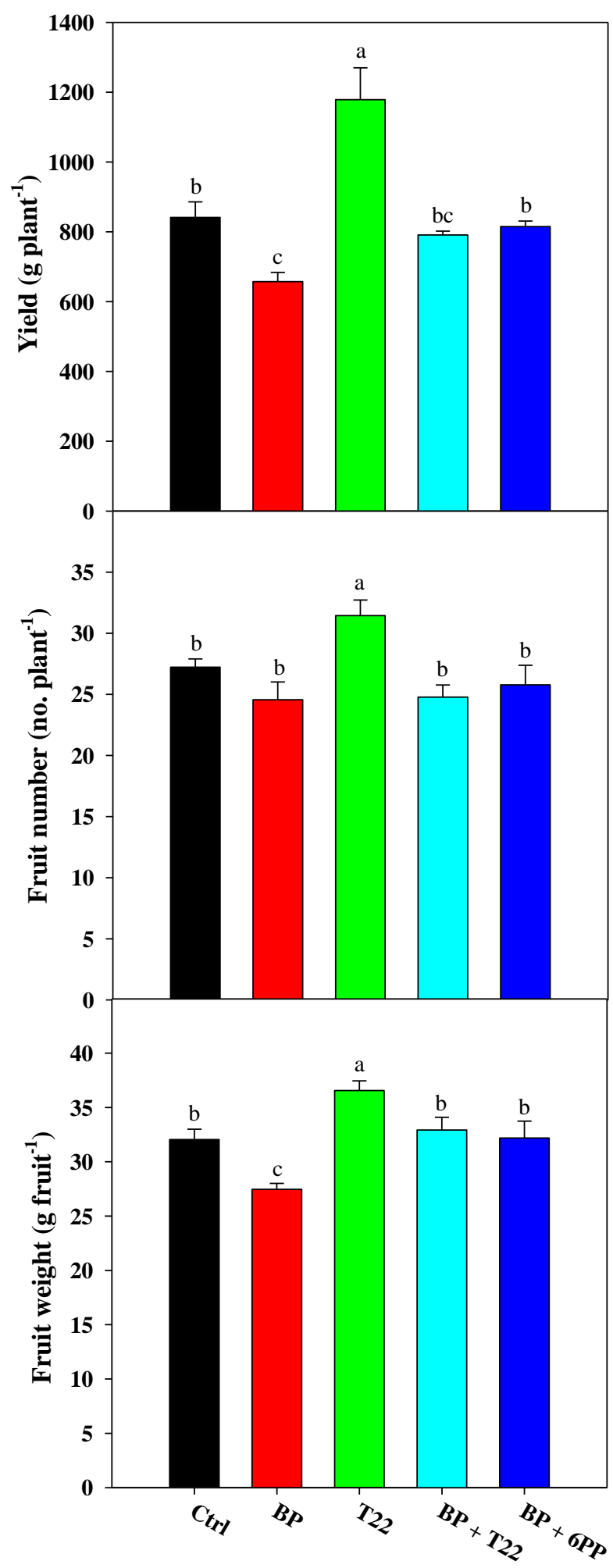

Figure 1. Effects of Trichoderma harzianum strain T22 (T22) or biopolymer (BP) applications alone, or in combinations of $\mathrm{BP}+\mathrm{T} 22$ or BP +6 -pentyl- $\alpha$-pyrone [6PP] (BP + 6PP), on fresh yield (A), fruit number per plant (B) and mean fruit weight (C) of greenhouse plum tomato. The control was not treated with biostimulants (Ctrl). Values are the means of three replicates \pm SE. Different letters indicate significant differences according to Duncan's test $(p=0.05)$. 
Table 1. Effects of treatments with Trichoderma harzianum strain T22 (T22) or biopolymer (BP) alone, or in combinations of $\mathrm{BP}+\mathrm{T} 22$ or $\mathrm{BP}+6$-pentyl- $\alpha$-pyrone $(6 \mathrm{PP})(\mathrm{BP}+6 \mathrm{PP})$ on shape index, fruit dry matter content, total soluble solids (TSS) content, and juice $\mathrm{pH}$ and electrical conductivity (EC) of greenhouse Pixel tomato fruits. The control was not treated with biostimulants (Ctrl).

\begin{tabular}{cccccc}
\hline Treatment & Shape Index & $\begin{array}{c}\text { Dry Matter Content } \\
(\mathbf{\%})\end{array}$ & $\begin{array}{c}\text { TSS } \\
\left({ }^{\circ} \text { Brix) }\right.\end{array}$ & pH & $\begin{array}{c}\text { EC } \\
\left(\mathbf{m S} \mathbf{~ c m}^{-1}\right)\end{array}$ \\
\hline Ctrl & $0.81 \mathrm{a}$ & 8.03 & 6.73 & 4.40 & $3.83 \mathrm{ab}$ \\
BP & $0.81 \mathrm{a}$ & 8.38 & 7.03 & 4.42 & $4.37 \mathrm{a}$ \\
T22 & $0.79 \mathrm{ab}$ & 8.00 & 6.63 & 4.39 & $3.87 \mathrm{ab}$ \\
$\mathrm{BP}+\mathrm{T} 22$ & $0.78 \mathrm{ab}$ & 7.67 & 6.47 & 4.33 & $4.48 \mathrm{a}$ \\
$\mathrm{BP}+6 \mathrm{PP}$ & $0.77 \mathrm{~b}$ & 7.79 & 6.80 & 4.40 & $3.48 \mathrm{~b}$ \\
Significance & $*$ & $\mathrm{NS}$ & $\mathrm{NS}$ & $\mathrm{NS}$ & $*$ \\
\hline
\end{tabular}

NS, non-significant or ${ }^{*}$, significant at $p \leq 0.05$. Different letters within each column indicate significant differences according to Duncan's multiple-range test $(p=0.05)$.

\subsection{Carbohydrates and Bioactive Metabolites Content}

The applications of T22 or BP alone or in combination, as a well as BP + 6PP treatments, did not cause a significant effect on starch (avg. $10.5 \mu \mathrm{mol} \mathrm{g}^{-1} \mathrm{dw}$ ), glucose (avg. $170.1 \mu \mathrm{mol} \mathrm{g}{ }^{-1} \mathrm{dw}$ ), fructose (avg. $34.7 \mu \mathrm{mol} \mathrm{g}^{-1} \mathrm{dw}$ ), sucrose (avg. $12.6 \mu \mathrm{mol} \mathrm{g}^{-1} \mathrm{dw}$ ) or polyphenols (avg. $5.0 \mathrm{mg} \mathrm{GAE} \mathrm{g}^{-1} \mathrm{dw}$ ) in the greenhouse tomato fruits (Table 2). However, only the content of lycopene, the major lipophilic antioxidant in tomatoes, was significantly increased $(p<0.001)$ upon applications with the fungus or the metabolite compared to the untreated control, as shown for T22 alone $(+49 \%)$, BP + T22 $(+40 \%)$ and BP $+6 \mathrm{PP}(+52 \%)$, with no significant differences noted between the two combined treatments (Table 2). Specifically, the lycopene content in the tomato fruits varied from $1.64 \mathrm{mg} \mathrm{g}^{-1} \mathrm{dw}$ in the control to 2.45 and $2.50 \mathrm{mg} \mathrm{g}^{-1} \mathrm{dw}$ in treatments with $\mathrm{T} 22$ alone and $\mathrm{BP}+6 \mathrm{PP}$, respectively.

Table 2. Effects of applications of Trichoderma harzianum strain T22 (T22) or biopolymer (BP) alone or in combinations $(\mathrm{BP}+\mathrm{T} 22$ or $\mathrm{BP}+6 \mathrm{PP})$ on the content of starch, glucose, fructose, sucrose, polyphenol and lycopene in greenhouse Pixel tomato fruits. The control was not treated with biostimulants (Ctrl).

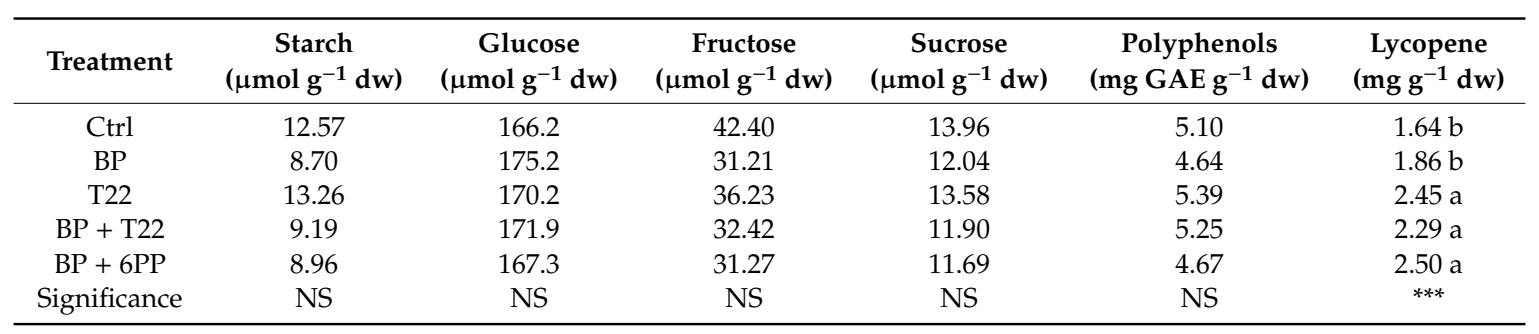

NS, non-significant or ${ }^{* * *}$, significant at $p \leq 0.001$. Different letters within each column indicate significant differences according to Duncan's multiple-range test $(p=0.05)$.

\subsection{Soluble Proteins and Free Amino Acids Contents}

Soluble protein content in control treatments was $20.7 \mathrm{mg} \mathrm{g}^{-1} \mathrm{dw}$ and this parameter was significantly increased by more than $20 \%$ with treatments of BP and BP + T22 (Table 3). In the evaluation of the mean total amino acids, it was observed that glutamate alone (avg. $187 \mu \mathrm{mol} \mathrm{g}^{-1} \mathrm{dw}$ ) accounted for $58.2 \%$ of the overall content, irrespective of the tomato treatments. Furthermore, glutamine (avg. $30.2 \mu \mathrm{mol} \mathrm{g}-1 \mathrm{dw}$ ), aspartate (avg. $26.0 \mu \mathrm{mol} \mathrm{g}^{-1} \mathrm{dw}$ ), asparagine (avg. $13.3 \mu \mathrm{mol} \mathrm{g}^{-1} \mathrm{dw}$ ), GABA (avg. $13.7 \mu \mathrm{mol} \mathrm{g}^{-1} \mathrm{dw}$ ) and arginine (avg. $11.3 \mu \mathrm{mol} \mathrm{g}^{-1} \mathrm{dw}$ ), even if detected in lower concentrations, all together represented $29.4 \%$ of the mean total amino acid content in all treatments (Table 3). Essential amino acids (the sum of arginine, histidine, isoleucine, leucine, lysine, methionine, phenylalanine, threonine, tryptophan and valine) accounted for $10 \%$ of total amino acids independently of treatment. In general, the single or combined applications of Trichoderma, metabolites or BP did not change the total amino acid content (avg. $321 \mu \mathrm{mol} \mathrm{g}^{-1} \mathrm{dw}$ ). However, it should be noted that all treatments resulted 
in a highly significant decrease $(p<0.001)$ in the glycine content in comparison to the control, from an initial value of $3.48 \mu \mathrm{mol} \mathrm{g}^{-1} \mathrm{dw}$ in the control and a decrease to an average value of $0.19 \mu \mathrm{mol} \mathrm{g}^{-1} \mathrm{dw}$ with the T22, $\mathrm{BP}+\mathrm{T} 22$ and $\mathrm{BP}+6 \mathrm{PP}$ applications (Table 3). In particular, it can be observed that the T22 treatment alone significantly increased $(p<0.05)$ the content of asparagine $(+37 \%)$, GABA $(+87 \%)$ and MEA $(+102 \%)$ compared to the untreated control. On the other hand, BP alone was also noted to strongly increase the content of GABA $(+105 \%)$ and MEA $(+85 \%)$. No other significant changes were induced by the single applications of $T$. harzianum strain $\mathrm{T} 22$ or BP alone or in the combinations $(\mathrm{BP}+$ $\mathrm{T} 22$ or $\mathrm{BP}+6 \mathrm{PP})$.

Table 3. Effects of Trichoderma harzianum strain T22 (T22) or biopolymer (BP) applications alone or in combinations $(\mathrm{BP}+\mathrm{T} 22$ or $\mathrm{BP}+6 \mathrm{PP})$ on soluble proteins, free amino acid profile and total amino acid content of greenhouse tomato fruits. The control was not treated with biostimulants (Ctrl).

\begin{tabular}{|c|c|c|c|c|c|c|}
\hline \multirow{2}{*}{ Chemical Compound } & \multicolumn{5}{|c|}{ Treatment } & \multirow{2}{*}{ Significance } \\
\hline & Ctrl & BP & T22 & $\mathrm{BP}+\mathrm{T} 22$ & $B P+6 P P$ & \\
\hline Soluble proteins $\left(\mathrm{mg} \mathrm{g}^{-1} \mathrm{dw}\right)$ & $20.66 c$ & $24.47 \mathrm{ab}$ & $21.47 \mathrm{bc}$ & $24.75 \mathrm{a}$ & $23.46 \mathrm{abc}$ & $*$ \\
\hline Alanine $\left(\mu \mathrm{mol} \mathrm{g}{ }^{-1} \mathrm{dw}\right)$ & 6.23 & 6.49 & 6.64 & 5.57 & 7.44 & NS \\
\hline Arginine $\left(\mu \mathrm{mol} \mathrm{g}^{-1} \mathrm{dw}\right)$ & 10.34 & 8.52 & 12.75 & 10.77 & 14.09 & NS \\
\hline Asparagine $\left(\mu \mathrm{mol} \mathrm{g}^{-1} \mathrm{dw}\right)$ & $11.66 \mathrm{~b}$ & $13.58 \mathrm{~b}$ & $16.02 \mathrm{a}$ & $12.01 \mathrm{~b}$ & $13.05 \mathrm{~b}$ & $*$ \\
\hline Aspartate $\left(\mu \mathrm{mol} \mathrm{g}{ }^{-1} \mathrm{dw}\right)$ & 25.15 & 28.12 & 26.46 & 21.71 & 28.42 & NS \\
\hline GABA $\left(\mu \mathrm{mol} \mathrm{g}^{-1} \mathrm{dw}\right)$ & $9.07 \mathrm{c}$ & $18.62 \mathrm{a}$ & $17.00 \mathrm{ab}$ & $11.39 \mathrm{bc}$ & $12.53 \mathrm{bc}$ & * \\
\hline Glutamine $\left(\mu \mathrm{mol} \mathrm{g}{ }^{-1} \mathrm{dw}\right)$ & 28.49 & 29.82 & 37.35 & 27.12 & 28.27 & NS \\
\hline Glutamate $(\mu \mathrm{mol} \mathrm{g}-1 \mathrm{dw})$ & $179.9 \mathrm{ab}$ & $231.3 \mathrm{a}$ & $186.6 \mathrm{ab}$ & $147.9 \mathrm{~b}$ & $189.1 \mathrm{ab}$ & $*$ \\
\hline Glycine $\left(\mu \mathrm{mol} \mathrm{g}^{-1} \mathrm{dw}\right)$ & $3.48 \mathrm{a}$ & $0.18 \mathrm{~b}$ & $0.15 \mathrm{~b}$ & $0.15 b$ & $0.27 \mathrm{~b}$ & $* * *$ \\
\hline Histidine $\left(\mu \mathrm{mol} \mathrm{g}^{-1} \mathrm{dw}\right)$ & 4.72 & 4.90 & 5.01 & 4.48 & 5.03 & NS \\
\hline Isoleucine $\left(\mu \mathrm{mol} \mathrm{g}^{-1} \mathrm{dw}\right)$ & 1.58 & 1.93 & 1.90 & 1.55 & 1.90 & NS \\
\hline Leucine $\left(\mu \mathrm{mol} \mathrm{g}{ }^{-1} \mathrm{dw}\right)$ & 2.29 & 2.84 & 2.71 & 2.17 & 2.75 & NS \\
\hline Lysine $\left(\mu \mathrm{mol} \mathrm{g}{ }^{-1} \mathrm{dw}\right)$ & 1.62 & 1.59 & 1.69 & 1.33 & 1.62 & ns \\
\hline $\operatorname{MEA}\left(\mu \mathrm{mol} \mathrm{g}{ }^{-1} \mathrm{dw}\right)$ & $0.46 \mathrm{~b}$ & $0.86 \mathrm{a}$ & $0.94 \mathrm{a}$ & $0.65 \mathrm{ab}$ & $0.81 \mathrm{a}$ & $*$ \\
\hline Methionine $\left(\mu \mathrm{mol} \mathrm{g}{ }^{-1} \mathrm{dw}\right)$ & 0.40 & 0.48 & 0.45 & 0.37 & 0.42 & NS \\
\hline Ornithine $\left(\mu \mathrm{mol} \mathrm{g}{ }^{-1} \mathrm{dw}\right)$ & 1.18 & 1.23 & 1.19 & 1.07 & 1.52 & NS \\
\hline Phenylalanine $\left(\mu \mathrm{mol} \mathrm{g}^{-1} \mathrm{dw}\right)$ & 5.61 & 6.92 & 6.46 & 5.21 & 7.18 & NS \\
\hline Proline $\left(\mu \mathrm{mol} \mathrm{g}^{-1} \mathrm{dw}\right)$ & 4.57 & 4.91 & 5.77 & 4.99 & 5.03 & NS \\
\hline Serine $\left(\mu \mathrm{mol} \mathrm{g}{ }^{-1} \mathrm{dw}\right)$ & 2.90 & 2.32 & 2.67 & 1.86 & 2.18 & NS \\
\hline Threonine $\left(\mu \mathrm{mol} \mathrm{g}{ }^{-1} \mathrm{dw}\right)$ & 1.86 & 1.54 & 2.04 & 1.23 & 1.80 & NS \\
\hline Tryptophan $\left(\mu \mathrm{mol} \mathrm{g}{ }^{-1} \mathrm{dw}\right)$ & 0.73 & 1.11 & 0.75 & 0.75 & 0.92 & NS \\
\hline Tyrosine $\left(\mu \mathrm{mol} \mathrm{g}^{-1} \mathrm{dw}\right)$ & 1.82 & 1.99 & 2.30 & 1.69 & 2.01 & NS \\
\hline Valine $\left(\mu \mathrm{mol} \mathrm{g}{ }^{-1} \mathrm{dw}\right)$ & 0.88 & 1.13 & 1.11 & 0.83 & 0.99 & NS \\
\hline Total amino acids $(\mu \mathrm{mol} \mathrm{g}-1 \mathrm{dw})$ & 304.9 & 370.4 & 337.9 & 264.8 & 327.3 & NS \\
\hline
\end{tabular}

NS, non-significant or ${ }^{*}{ }^{* * *}$, significant at $p \leq 0.05,0.001$, respectively. Different letters within each column indicate significant differences according to Duncan's multiple-range test $(p=0.05)$.

\subsection{Principal Component Analysis}

To obtain an overview of crop productivity and the compositional profile of greenhouse tomato with the different Trichoderma, metabolite or BP applications, a principal component analysis (PCA) was performed on all measured parameters (Figure 2). The first three principal components (PCs) were related, with eigenvalues higher than 1 , and explained $85.3 \%$ of the total variance, with PC1, PC2 and PC3 accounting for $34.3 \%, 29.0 \%$ and $22.0 \%$, respectively (data not shown). PC1 was positively correlated to total amino acids, essential amino acids, particularly branched chain amino acids (BCAAs), tyrosine, aspartate, asparagine, MEA, GABA, alanine, glutamate, glutamine and juice $\mathrm{pH}$. PC1 was also negatively correlated to glycine and juice EC. Moreover, PC2 was positively correlated to soluble proteins, TSS and glucose, while PC2 was negatively correlated to starch, fruit number, fresh yield, sucrose, fruit mean weight, polyphenols, fructose and serine (Figure 2). The treatments were well separated and distributed in the loading plot. The control was positioned in the middle of the lower left quadrant, strongly correlated to glycine content. The combination of BP + T22 was positioned on the negative side of PC1 in the upper left quadrant, highly correlated with EC (Figure 2). Treatments with 
$\mathrm{BP}+6 \mathrm{PP}$ and $\mathrm{BP}$ were positioned on the positive side of $\mathrm{PC} 1$ in the right upper quadrant, correlated to soluble proteins, TSS, glutamate and GABA. Meanwhile, T22 treatment was in the lower right quadrant on the negative side of PC2 and was characterized by high yield and yield components and high starch, glutamine, proline tyrosine, asparagine and serine contents (Figure 2). The distribution of the treatments across the measured factors in PC2 was strongly attributed to the presence of the biopolymer.

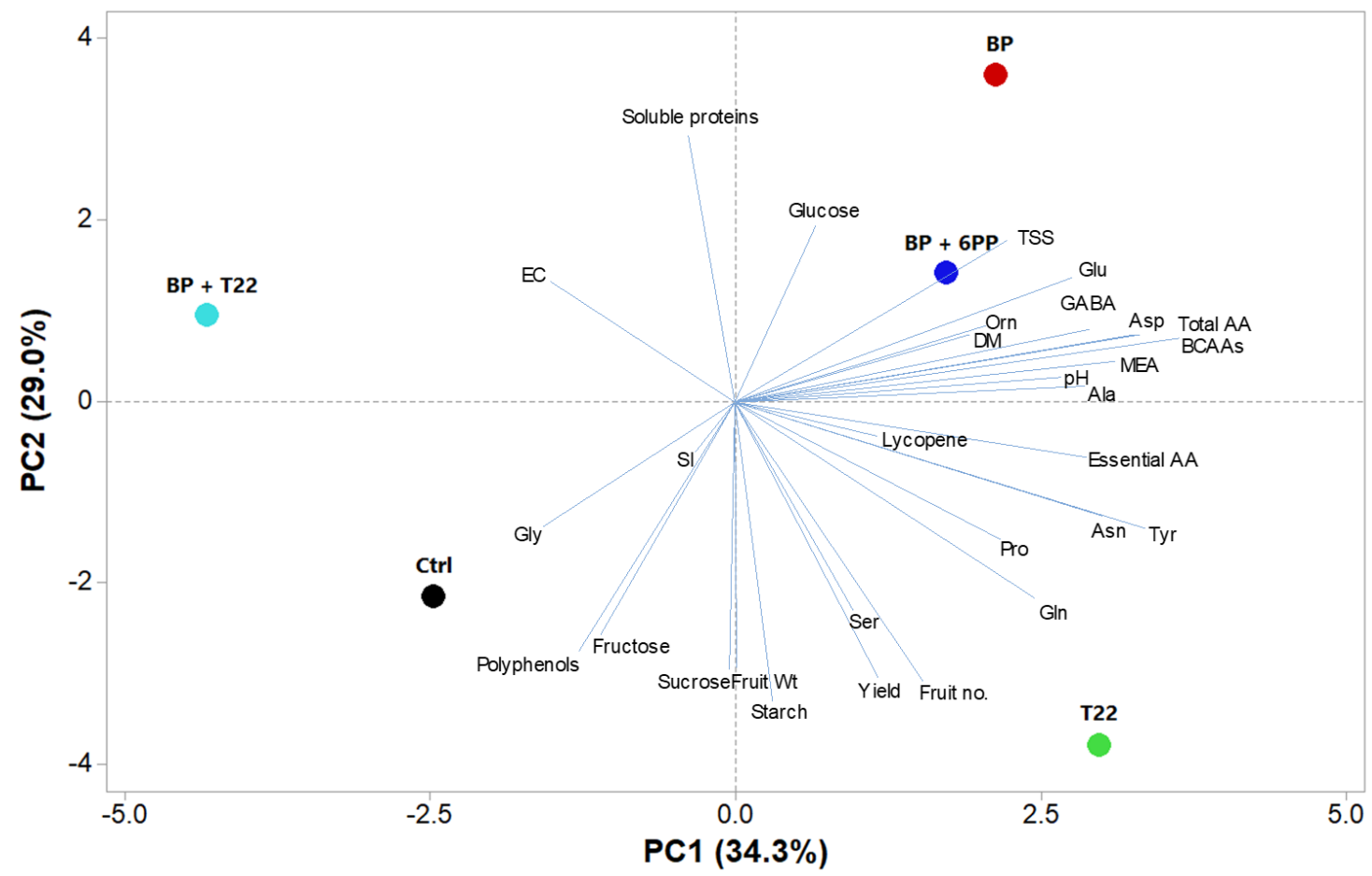

Figure 2. Principal component loading plot and scores of principal component analysis (PCA) of morphological parameters, starch, soluble carbohydrates, polyphenols, lycopene and soluble protein and amino acid profiles of greenhouse tomato as affected by different treatments: Trichoderma harzianum strain T22 (T22) or biopolymer (BP) alone or in combination (BP + T22 or BP + 6PP). The control was not treated with biostimulants (Ctrl).

\section{Discussion}

The use of Trichoderma spp., or other endophytic fungi, as a promising tool and sustainable approach in modern agriculture, has emerged in the last twenty years due to the multifaceted properties and positive effects observed on horticultural and agricultural crops $[14,16,39]$. Hence, the recent movement by researchers, farmers and biotechnological companies to evaluate new Trichoderma-based products developed to enhance and optimize bioformulations with beneficial fungi and/or their bioactive metabolites on crops by using novel delivery systems $[9,12,15]$. To this end, the present study tested and demonstrated the effectiveness of a biopolymer composed of vegetal carboxymethyl cellulose and synthetic Pluronic F-127 used alone, but more importantly in combination with T. harzianum T22, as well as with 6PP, an active Trichoderma metabolite known to exert multiple beneficial effects on plants, on the production of Pixel tomatoes in the greenhouse.

The first important confirmation was that inoculation of the Pixel tomato with Trichoderma harzianum T22 significantly improved the marketable yield, fruit mean weight and number of fruits per plant compared to untreated plants. This effect could be attributable to several concomitant beneficial effects elicited by this fungus, including crop protection from pathogens [9] and the growth promotion of root biomass and architecture, as well as increased nutrient uptake and transport (i.e., soil acidification, and $\mathrm{Fe}$ and $\mathrm{Cu}$ chelation) [40]. Compounds similar to plant hormones, such as indole-3-acetic acid (IAA), indole-3-acetaldehyde (IAAld) and indole-3-ethanol (IEt), are synthetized by Trichoderma spp. [41], 
which stimulate lateral root formation, thus increasing the root surface area, creating niches for fungal colonization, as well as indirectly improving the water and nutrient uptake capacity of the plant and the processes associated with photosynthesis $[9,12,15,19,42]$. Although the secondary metabolite 6PP was previously reported to exert an auxin-like activity and promote plant growth [33], it did not produce the significant effects on tomato marketable yield and fruit production as noted with the use of the living Trichoderma fungus in this study. The fungus is probably able to not only to enhance the physiological active uptake mechanisms of the plant, but to act directly on the solubilization of various nutrients in the soil rhizosphere, such as rock phosphate, iron, copper and divalent ions, or to produce siderophores, which render these elements available to the plant [14]. The positive biological activities on the plant were inhibited in presence of BP, since fruit growth and yield observed with Trichoderma alone were significantly higher, but when the fungus or the metabolite were combined with $\mathrm{BP}$, the beneficial action on the greenhouse tomato was no longer obtained.

In contrast, the treatment with BP alone, or in combination with T. harzianum $\mathrm{T} 22$, determined a significant increase in protein content in the tomatoes, probably due to the effect on metabolic processes that increase NUE. In fact, carboxymethyl cellulose hydrogel is known to facilitate nutrient availability in the rhizosphere, enhancing not only nitrogen uptake, but in particular the absorption of important bivalent ions by the plant [43]. For example, magnesium $\left(\mathrm{Mg}^{2+}\right)$ is the central atom in the tetrapyrrole ring of chlorophyll molecules and can act as an activator of more than 300 enzymes, thus playing a key role in various physiological and biochemical processes, including chlorophyll biosynthesis and photosynthesis [44]. In addition, manganese $\left(\mathrm{Mn}^{2+}\right)$ is necessary for chlorophyll synthesis, but above all, it plays a key role in the oxygen evolving complex (OEC) of photosystem II, since four atoms of $\mathrm{Mn}^{2+}$ are required to split water [45]. Therefore, the uptake of these elements by the plant contributes to the metabolic processes that influence the quality of the fruits.

The treatment with T. harzianum T22 also demonstrated an improvement in nitrogen metabolism in plum tomato, as noted by the increase in the asparagine content, the most common amide used for the long-distance transport of nitrogen throughout the plant. This effect could be due to the ability of fungi, like Trichoderma spp., to promote the uptake of nitrogen, as observed in field grown corn [14], or to increase the expression of genes encoding for key enzymes involved in the assimilatory reduction pathway, such as nitrate reductase (NR) [46,47]. Furthermore, the increase in asparagine and the strong decrease in glycine, a photorespiratory amino acid, were not accompanied by a statistically significant decrease in the starch or soluble protein content in fruits that could imply that T. harzianum T22 was able to increase the photosynthetic efficiency while decreasing the photorespiratory activity of the treated plant. Alternatively, it is possible that the fungus maximized the re-assimilation of photorespiratory products through a rapid re-use of glycine and ammonium released during photorespiration, thus resulting in a de novo synthesis of amides [48].

In addition, both of the single treatments of T. harzianum T22 and BP revealed a significant increase in GABA, a non-protein amino acid that can act as a temporary deposit of nitrogen to reduce the accumulation of excess ammonium produced by photorespiration, thus allowing the stationary control of $\mathrm{pH}$, since protons are consumed in the process [49]. The synthesis of GABA, catalyzed by the enzyme glutamate decarboxylase (GAD), releases $\mathrm{CO}_{2}$, which allows the Calvin cycle to function with closed or semi-closed stomata under drought stress conditions, thus reducing the pressure on the photosynthetic electron chain and decreasing ROS and photodamage in plant tissues [50]. The zwitterion form of GABA is able to act as an osmolyte without toxic effects in balancing the decrease in water potential during cellular dehydration and functioning as an antioxidant for the stabilization and protection of thylakoids and macromolecules [50]. Furthermore, it has been reported that GABA has many beneficial effects on human health, including hypotensive effects, the enhancement of immune functions under stress, the prevention of cancer and diabetes and control of blood cholesterol levels [51-53].

The increase in GABA did not determine a decrease in its precursor, glutamate, which remained stable except for a non-significant decrease with the treatment BP + T22. The stability of glutamate 
content is of primary importance since it can affect tomato flavor and fruit palatability, as it has been reported to elicit an intense umami taste [54].

Trichoderma harzianum T22 and BP alone, as well as the BP + 6PP treatment, also determined an increase in the monoethanolamine (MEA) content, an amino acid derivative important for the synthesis or regeneration of phospholipids, derived by the decarboxylation of the photorespiratory amino acid serine. Therefore, the application of these treatments allowed tomato plants to reuse the photorespiratory amino acids and ammonium to synthesize useful metabolites, thus reducing the pressure of photorespiration on plant metabolism in favor of optimizing the processes involved in photosynthesis.

The content of lycopene significantly increased with all the tested treatments that included T. harzianum T22 or the fungal secondary metabolite 6PP. It is well documented that lycopene is the main lipophilic antioxidant found in tomato fruits, and its increase is particularly important because it could assure a longer shelf-life of plum tomatoes. On the contrary, polyphenols that behave as free radical scavengers and take part in redox reactions due to their ability to transport protons and electrons and confer resistance to abiotic stresses and pathogens [54,55], were not affected by Trichoderma, metabolites or BP applications, as recently found by Caruso et al. [56]. This result could mean that there is a basal constitutive amount of polyphenols in plum tomatoes that is independent of influences by external stimuli. Lycopene present in tomato products also has important human health properties. It can be involved in protection against chronic disorders, such as cardiovascular disease or prostate, respiratory and digestive epithelial cancers [57]. Recent epidemiological data have proven that it exerts cardiovascular protection by decreasing High-Density Lipoprotein (HDL) -associated inflammation and modulating HDL functionality [58]. Moreover, lycopene can scavenge ROS, in particular hydroxyl radicals, and stimulate antioxidant enzymes, such as superoxide dismutase, glutathione peroxidase and glutathione reductase, thus preventing oxidative stress-mediated carcinogenesis [59-61].

The development of biologically based products for agriculture is complex due to the mix of components in the formulation, particularly if they include living microorganisms. In nature, the interactions among plants, microbes and the substances in the environment are multiple, various and influence the agroecosystem of crop production in diverse and often unpredictable ways.

\section{Materials and Methods}

\subsection{Biostimulants, Plant Material and Greenhouse Experimental Design}

Four biostimulant treatments were used: (i) Trichoderma harzianum strain T22 (T22; the commercial formulation of Trianum-P, Koppert Biological Systems; used at the label recommendation of a final concentration $10^{7}$ spore $\mathrm{mL}^{-1}$ ), (ii) biopolymer (BP; diluted in water), (iii) biopolymer $+\mathrm{T} 22$ $\left(10^{7}\right.$ spore $\left.\mathrm{mL}^{-1}\right)$ and (iv) biopolymer +6 -pentyl- $\alpha$-pyrone (6PP; concentration $\left.10^{-6} \mathrm{M}\right)$. A metabolite derived from Trichoderma sp., 6PP, was purchased from Sigma Aldrich (St. Louis, MO, USA). The biopolymer formulation was a combination of: carboxymethyl cellulose (CMC; average molecular weight (Mw) of $250 \mathrm{kDa}$ ) and Pluronic F127 (PF-127; (PPO)100(PEO)65(PPO)100, Mw = $12500 \mathrm{~g} \mathrm{~mol}^{-1}$; Sigma-Aldrich, Milan, Italy). A stock biopolymer solution was prepared by solubilizing CMC (1\% $v / v)$ and PF-127 (1\% v/v) in water with mechanical stirring for $4 \mathrm{~h}$, in order to achieve the complete dissolution of the polymers. The stock solution was then diluted with water (1:1) before adding T22 spores or 6PP, prior to plant application in the field.

Mini plum tomato (Solanum lycopersicum L.) seedlings variety Pixel F1 (indeterminate growth; ISI Sementi SpA, Fidenza, Italy) were transplanted to a polyethylene tunnel greenhouse located at the University of Naples Federico II, Portici (NA), south Italy $\left(40^{\circ} 49^{\prime} \mathrm{N}, 14^{\circ} 15^{\prime} \mathrm{E} ; 72 \mathrm{~m}\right.$ a.s.1.) on 4 April 2019. Prior to transplant, $1.4 \mathrm{~kg} \mathrm{~m}^{-2}$ of manure (32-7-2) was added to the soil and mixed. At the time of transplant, the seedling roots were dipped in solutions containing the four separated liquid inocula and the controls were treated with water. The tomato plants were transplanted in single rows at $1 \mathrm{~m}$ 
distance between rows, while within the rows, tomato seedlings were at a $30 \mathrm{~cm}$ distance, accounting for a density of 3.3 plants $\mathrm{m}^{-2}$.

The four treatments and the control were arranged in a randomized complete block design with three replicates, which consisted of fifteen plants each. The biostimulant treatments were repeated on 16 May, 7 June and 4 July by manually watering each plant with the inoculum at volumes of 25, 100 and $250 \mathrm{~mL}$, respectively.

The plants were irrigated using a drip irrigation system, and during the growing cycle, $2.5 \mathrm{~kg}$ of calcium nitrate (Calcinit, YaraLiva, Milano, Italy) was applied three times via fertigation in two-week intervals, starting on 31 May. Foliar treatments consisted of a mix of calcium and magnesium (Calimag, Meristem, Moncada, Spain) applied between mid-June and beginning of July, while Bacillus thuringiensis vr. kurstaki (BAC MK, Comercial Química Massó, S.A., Barcelona, Spain) was applied four times, in 10-day cycles, in intervals starting in the beginning of June.

\subsection{Yield Components, Sampling and Fruit Quality Assessments}

Harvesting was performed once weekly starting on 12 July to determine the yield and yield components. Fruits were collected from the 3rd cluster for determining fruit shape index and performing the qualitative analysis. Throughout the harvest period, the marketable yield, the number of fruits per plant and the mean fruit weight were measured on forty-five plants from each treatment. Deformed or misshaped fruits were discarded because of unmarketable quality. A subsample of fresh fruits was used for the determination of shape index, total soluble solid content, juice $\mathrm{pH}$ and electrical conductivity (EC), while the remaining subsample was shock-frozen in liquid nitrogen, lyophilized and stored at $-80^{\circ} \mathrm{C}$ until further chemical analyses of: starch, soluble carbohydrates, polyphenols, lycopene, soluble proteins and free amino acids.

The shape index was determined as the ratio of fruit equatorial and meridian diameters. Mini plum tomato fruits were homogenized in a Waring ${ }^{\circledR}$ blender ( 2 L capacity; Model HGB140, CA, USA) for $1 \mathrm{~min}$, the liquid was filtered through a double cheesecloth to remove the pulp, then the juice was subjected to measurements of total soluble solid (TSS) content with a digital Atago N1 refractometer (Atago Co. Ltd., Tokyo, Japan), juice $\mathrm{pH}$ was measured by a HI-9023 pH meter (Hanna Instruments, Padova, Italy) and juice EC was evaluated by a HI-99301 EC meter (Hanna Instruments, Padova, Italy). Fruit dry matter content was assessed as a percentage of fresh mass after desiccation at $75^{\circ} \mathrm{C}$ for about 3 days, until constant weight was achieved.

\subsection{Starch and Soluble Carbohydrate Analysis}

Soluble sugars ( $\mu \mathrm{mol} \mathrm{g}^{-1} \mathrm{dw}$ ) were estimated in the supernatant of ethanolic extracts of lyophilized tomato samples by a coupled enzyme assay based on NAD-linked enzymatic reactions and the determination of NADH at $340 \mathrm{~nm}$ recorded by a Synergy HT spectrophotometer (BioTEK Instruments, Bad Friedrichshall, Germany) [54]. This assay was also used to quantify starch in the pellets of the same ethanolic extracts after hydrolysis to glucose, according to Carillo et al. [54].

\subsection{Polyphenol and Lycopene Analysis}

The total polyphenol content was determined by using the Singleton [62] Folin-Ciocalteu method with modifications, as described in Carillo et al. [63]. The polyphenol concentration was expressed as gallic acid equivalents (GAE) (mg GAE g $\left.{ }^{-1} \mathrm{dw}\right)$.

Lycopene concentration ( $\mathrm{mg} \mathrm{g}^{-1} \mathrm{dw}$ ) was evaluated according to Sadler et al. [64] from lyophilized tomato samples (15 $\mathrm{mg})$ using the modifications described in Carillo et al. [54].

\subsection{Soluble Proteins, Free and Total Amino Acid Analysis}

Soluble proteins ( $\mathrm{mg} \mathrm{g}^{-1} \mathrm{dw}$ ) were extracted from $10 \mathrm{mg}$ of lyophilized tomato plant material with $1 \mathrm{~mL}$ of $200 \mathrm{mM}$ Tris- $\mathrm{HCl} 200 \mathrm{mM} \mathrm{pH} 7.5$ containing $500 \mathrm{mM} \mathrm{MgCl} 2$ at $4{ }^{\circ} \mathrm{C}$ for $24 \mathrm{~h}$, and assayed by the Bio-Rad Protein Assay, based on the Bradford method [63]. 
Primary amino acids and proline $\left(\mu \mathrm{mol} \mathrm{g}{ }^{-1} \mathrm{dw}\right)$ were extracted from $10 \mathrm{mg}$ of lyophilized fruits in $1 \mathrm{~mL}$ ethanol:water $(40: 60 \mathrm{v} / \mathrm{v})$ overnight at $4{ }^{\circ} \mathrm{C}$, and determined by HPLC after pre-column derivatization with o-phthaldialdehyde (OPA), according to Carillo et al. [54]. Proline was estimated in the same ethanol extract through an acid ninhydrin-based method modified by Woodrow et al. [48].

\subsection{Statistics, Principal Component Analysis and Percentage Increase}

A one-way analysis of variance (ANOVA) of all data was performed using the software package SPSS 13 for Windows 2001. Duncan's multiple-range test was used to analyze separated means with a cut-off for statistical significance at $p<0.05$. A principal component analysis was employed to investigate how the dominant quanti-qualitative parameters set clustered according to the treatments by using Minitab ${ }^{\circledR} 18$ statistical software (Minitab LLC, State College, PA, USA) [27,65]. The percentage increases were calculated as the difference between the treated sample values minus untreated sample values (increase), divided by the untreated sample values and multiplied by 100 .

\section{Conclusions}

Company R\&D programs often have a single objective for the final commercial product, and that is to satisfy the demands for increased crop yield or improved productivity from the producers. Although the interests of the consumer may be well satisfied by the wide assortment and availability of goods in the supermarket, their interests may also be aimed at the evaluation of the qualitative and health properties of the purchased food product. Our greenhouse experiment on plum tomato confirmed the ability of T. harzianum T22 to improve crop productivity $(+40 \%)$ and the quality of the produce in terms of lycopene, asparagine and GABA compared to the untreated control. However, the other treatments were also able to increase the content of GABA or lycopene, enhancing the premium quality of plum tomatoes. Therefore, this investigation into the development of new bioformulations not only confirmed that T. harzianum $\mathrm{T} 22$ or BP alone, or in combination with $\mathrm{T} 22+\mathrm{BP}$ or $6 \mathrm{PP}+\mathrm{BP}$, not only represent a promising strategy for improving the yield and quality of horticultural crops such tomato, but also demonstrate that in the absence of apparent increased productivity in the plant, some treatments are still able to produce beneficial nutritional effects in the fruit. The synthesis of bioformulations, based on findings from research such as the present study, aid in the establishment of sustainable cropping systems, as well as in the development of biofunctional foods, thus supporting the direction of agricultural advancement in the future.

Author Contributions: Conceptualization, S.L.W. and Y.R.; methodology, P.C., Y.R., A.B., S.L. and S.L.W.; software, P.C., C.E.-N.; validation, E.C., S.L. and S.L.W.; formal analysis, P.C., C.E.-N., E.C. and G.M.F.; data curation, C.E.-N., E.C.; writing-original draft preparation, P.C., Y.R., C.E.-N. and S.L.W.; writing-review and editing, P.C., Y.R., F.V., A.B. and S.L.W.; visualization, Y.R., P.C., G.C. and S.L.W.; supervision, Y.R., P.C. and S.L.W.; project administration, F.V. and S.L.W.; funding acquisition, F.V. and S.L.W. All authors have read and agreed to the published version of the manuscript.

Funding: This research was funded by POR FESR CAMPANIA 2014/2020- O.S. 1.1 [grant number Bioagro 559]; MISE CRESO [grant number Protection no. F/050421/01-03/X32]; Università degli Studi della Campania Luigi Vanvitelli, [grant number VALERE: VAnviteLli pEr la RicErca].

Acknowledgments: The authors would like to thank: Koppert Biological Systems, Rotterdam, the Netherlands for providing the commercial formulation of the biofungicide Trianum P (T22) and Mario Di Gennaro, Salvatore Spano and Augusto Verdino for the technical assistance. Finally, we would like to thank Antonio Pannico for the statistical analysis.

Conflicts of Interest: The authors declare no conflict of interest.

\section{References}

1. Shennan, C.; Krupnik, T.; Baird, G.; Cohen, H.; Forbush, K.; Lovell, R.; Olimpi, E. Organic and Conventional Agriculture: A Useful Framing? Annu. Rev. Environ. Resour. 2017, 42. [CrossRef]

2. Rouphael, Y.; Colla, G. Editorial: Biostimulants in Agriculture. Front. Plant Sci. 2020, 11. [CrossRef] 
3. FAO. Transforming the World through Food and Agriculture_FAO and the 2030 Agenda for Sustainable Development; FAO: Rome, Italy, 2019; p. 36. Available online: http://www.fao.org/documents/card/en/c/CA5299EN/ (accessed on 4 May 2020).

4. Witkowicz, R.; Biel, W.; Chłopicka, J.; Galanty, A.; Gleń-Karolczyk, K.; Skrzypek, E.; Krupa, M. Biostimulants and microorganisms boost the nutritional composition of buckwheat (Fagopyrum esculentum Moench) Sprouts. Agronomy 2019, 9, 469. [CrossRef]

5. Du Jardin, P. Plant biostimulants: Definition, concept, main categories and regulation. Sci. Hortic. 2015, 196, 3-14. [CrossRef]

6. Colla, G.; Rouphael, Y. Biostimulants in horticulture. Sci. Hortic. 2015, 196, 1-2. [CrossRef]

7. Vinale, F.; Sivasithamparam, K.; Ghisalberti, E.L.; Marra, R.; Woo, S.L.; Lorito, M. Trichoderma-plant-pathogen interactions. Soil Biol. Biochem. 2008, 40,1-10. [CrossRef]

8. Morán-Diez, M.E.; Tranque, E.; Bettiol, W.; Monte, E.; Hermosa, R. Differential response of tomato plants to the application of three Trichoderma species when evaluating the control of Pseudomonas syringae populations. Plants 2020, 9, 626. [CrossRef]

9. Fiorentino, N.; Ventorino, V.; Woo, S.L.; Pepe, O.; De Rosa, A.; Gioia, L.; Romano, I.; Lombardi, N.; Napolitano, M.; Colla, G.; et al. Trichoderma-based biostimulants modulate rhizosphere microbial populations and improve N uptake efficiency, yield, and nutritional quality of leafy vegetables. Front. Plant Sci. 2018, 9. [CrossRef]

10. Pascale, A.; Vinale, F.; Manganiello, G.; Nigro, M.; Lanzuise, S.; Ruocco, M.; Marra, R.; Lombardi, N.; Woo, S.; Lorito, M. Trichoderma and its secondary metabolites improve yield and quality of grapes. Crop Prot. 2017, 92. [CrossRef]

11. Woo, S.; Ruocco, M.; Vinale, F.; Nigro, M.; Marra, R.; Lombardi, N.; Pascale, A.; Lanzuise, S.; Manganiello, G.; Lorito, M. Trichoderma-based products and their widespread use in agriculture. Open Mycol. J. 2014, 8. [CrossRef]

12. Colla, G.; Rouphael, Y.; Di Mattia, E.; El-Nakhel, C.; Cardarelli, M. Co-inoculation of Glomus intraradices and Trichoderma atroviride acts as a biostimulant to promote growth, yield and nutrient uptake of vegetable crops. J. Sci. Food Agric. 2015, 95, 1706-1715. [CrossRef] [PubMed]

13. Stewart, A.; Hill, R. Chapter 31-Applications of Trichoderma in Plant Growth Promotion. In Biotechnology and Biology of Trichoderma; Gupta, V.K., Schmoll, M., Herrera-Estrella, A., Upadhyay, R.S., Druzhinina, I., Tuohy, M.G., Eds.; Elsevier: Amsterdam, The Netherlands, 2014; pp. 415-428. [CrossRef]

14. Harman, G.E.; Howell, C.R.; Viterbo, A.; Chet, I.; Lorito, M. Trichoderma species-Opportunistic, avirulent plant symbionts. Nat. Rev. Microbiol. 2004, 2, 43-56. [CrossRef]

15. Rouphael, Y.; Carillo, P.; Colla, G.; Fiorentino, N.; Sabatino, L.; El-Nakhel, C.; Giordano, M.; Pannico, A.; Cirillo, V.; Shabani, E.; et al. Appraisal of combined applications of Trichoderma virens and a biopolymer-based biostimulant on lettuce agronomical, physiological, and qualitative properties under variable $\mathrm{N}$ regimes. Agronomy 2020, 10, 196. [CrossRef]

16. López-Bucio, J.; Pelagio-Flores, R.; Herrera-Estrella, A. Trichoderma as biostimulant: Exploiting the multilevel properties of a plant beneficial fungus. Sci. Hortic. 2015, 196, 109-123. [CrossRef]

17. Van Oosten, M.J.; Dell'Aversana, E.; Ruggiero, A.; Cirillo, V.; Gibon, Y.; Woodrow, P.; Maggio, A.; Carillo, P. Omeprazole treatment enhances nitrogen use efficiency through increased nitrogen uptake and assimilation in corn. Front. Plant Sci. 2019, 10. [CrossRef] [PubMed]

18. Molla, A.H.; Manjurul Haque, M.; Amdadul Haque, M.; Ilias, G.N.M. Trichoderma-Enriched Biofertilizer enhances production and nutritional quality of tomato (Lycopersicon esculentum Mill.) and minimizes NPK fertilizer use. Agric. Res. 2012, 1, 265-272. [CrossRef]

19. Macías-Rodríguez, L.; Guzmán-Gómez, A.; García-Juárez, P.; Contreras-Cornejo, H.A. Trichoderma atroviride promotes tomato development and alters the root exudation of carbohydrates, which stimulates fungal growth and the biocontrol of the phytopathogen Phytophthora cinnamomi in a tripartite interaction system. FEMS Microbiol. Ecol. 2018, 94. [CrossRef]

20. Manganiello, G.; Sacco, A.; Ercolano, M.R.; Vinale, F.; Lanzuise, S.; Pascale, A.; Napolitano, M.; Lombardi, N.; Lorito, M.; Woo, S.L. Modulation of tomato response to Rhizoctonia solani by Trichoderma harzianum and its secondary metabolite harzianic acid. Front. Microbiol. 2018, 9. [CrossRef] 
21. Vinale, F.; Nigro, M.; Sivasithamparam, K.; Flematti, G.; Ghisalberti, E.L.; Ruocco, M.; Varlese, R.; Marra, R.; Lanzuise, S.; Eid, A.; et al. Harzianic acid: A novel siderophore from Trichoderma harzianum. FEMS Microbiol. Lett. 2013, 347, 123-129. [CrossRef]

22. De Tommaso, G.; Salvatore, M.M.; Nicoletti, R.; DellaGreca, M.; Vinale, F.; Bottiglieri, A.; Staropoli, A.; Salvatore, F.; Lorito, M.; Iuliano, M.; et al. Bivalent metal-chelating properties of harzianic acid produced by Trichoderma pleuroticola associated to the gastropod melarhaphe neritoides. Molecules 2020, 25, 2147. [CrossRef]

23. Azarmi, R.; Hajieghrari, B.; Giglou, A. Effect of Trichoderma isolates on tomato seedling growth response and nutrient uptake. Afr. J. Biotechnol. 2011, 10, 5850-5855. [CrossRef]

24. Salwan, R.; Kumari, N.; Sharma, V. Bioactive Volatile Metabolites of Trichoderma: An Overview; Springer: Singapore, 2019; pp. 87-111. [CrossRef]

25. Coppola, M.; Diretto, G.; Digilio, M.C.; Woo, S.L.; Giuliano, G.; Molisso, D.; Pennacchio, F.; Lorito, M.; Rao, R. Transcriptome and metabolome reprogramming in tomato plants by Trichoderma harzianum strain T22 primes and enhances defense responses against aphids. Front. Physiol. 2019, 10, 745. [CrossRef] [PubMed]

26. Rouphael, Y.; Raimondi, G.; Lucini, L.; Carillo, P.; Kyriacou, M.C.; Colla, G.; Cirillo, V.; Pannico, A.; El-Nakhel, C.; De Pascale, S. Physiological and metabolic responses triggered by omeprazole improve tomato plant tolerance to $\mathrm{NaCl}$ Stress. Front. Plant Sci. 2018, 9. [CrossRef] [PubMed]

27. Carillo, P.; Woodrow, P.; Raimondi, G.; El-Nakhel, C.; Pannico, A.; Kyriacou, M.; Colla, G.; Mori, M.; Giordano, M.; De Pascale, S.; et al. Omeprazole promotes chloride exclusion and induces salt tolerance in greenhouse basil. Agronomy 2019, 9, 355. [CrossRef]

28. Carillo, P.; Colla, G.; Fusco, G.M.; Dell'Aversana, E.; El-Nakhel, C.; Giordano, M.; Pannico, A.; Cozzolino, E.; Mori, M.; Reynaud, H.; et al. Morphological and physiological responses induced by protein hydrolysate-based biostimulant and nitrogen rates in greenhouse spinach. Agronomy 2019, 9, 450. [CrossRef]

29. Harman, G.E. Overview of mechanisms and uses of Trichoderma spp. Phytopathology 2006, 96, 190-194. [CrossRef]

30. Collins, R.P.; Halim, A.F. Characterization of the major aroma constituent of the fungus Trichoderma viride. J. Agric. Food Chem. 1972, 20, 437-438. [CrossRef]

31. Scarselletti, R.; Faull, J.L. In vitro activity of 6-pentyl- $\alpha$-pyrone, a metabolite of Trichoderma harzianum, in the inhibition of Rhizoctonia solani and Fusarium oxysporum f. sp. lycopersici. Mycol. Res. 1994, 98, 1207-1209. [CrossRef]

32. Vinale, F.; Sivasithamparam, K.; Ghisalberti, E.; Woo, S.; Nigro, M.; Marra, R.; Lombardi, N.; Pascale, A.; Ruocco, M.; Lanzuise, S.; et al. Trichoderma secondary metabolites active on plants and fungal pathogens. Open Mycol. J. 2014, 8. [CrossRef]

33. Vinale, F.; Sivasithamparam, K.; Ghisalberti, E.; Marra, R.; Barbetti, M.J.; Li, H.; Woo, S.; Lorito, M. A novel role for the Trichoderma-plant interaction Trichoderma secondary metabolites in the interactions with plants. Physiol. Mol. Plant Pathol. 2008, 72, 80-86. [CrossRef]

34. Lucini, L.; Rouphael, Y.; Cardarelli, M.; Bonini, P.; Baffi, C.; Colla, G. A Vegetal biopolymer-based biostimulant promoted root growth in melon while triggering brassinosteroids and stress-related compounds. Front. Plant Sci. 2018, 9. [CrossRef]

35. Le Mire, G.; Nguyen, M.L.; Fassotte, B.; du Jardin, P.; Verheggen, F.; Delaplace, P.; Jijakli, M. Review: Implementing plant biostimulants and biocontrol strategies in the agroecological management of cultivated ecosystems. Biotechnol. Agron. Soc. Environ. 2016, 20, 299-313. [CrossRef]

36. Guilherme, M.R.; Aouada, F.A.; Fajardo, A.R.; Martins, A.F.; Paulino, A.T.; Davi, M.F.T.; Rubira, A.F.; Muniz, E.C. Superabsorbent hydrogels based on polysaccharides for application in agriculture as soil conditioner and nutrient carrier: A review. Eur. Polym. J. 2015, 72, 365-385. [CrossRef]

37. Makvandi, P.; Ali, G.W.; Della Sala, F.; Abdel-Fattah, W.I.; Borzacchiello, A. Hyaluronic acid/corn silk extract based injectable nanocomposite: A biomimetic antibacterial scaffold for bone tissue regeneration. Mater. Sci. Eng. C 2020, 107, 110195. [CrossRef] [PubMed]

38. Krauss, S.; Schnitzler, W.H.; Grassmann, J.; Woitke, M. The Influence of Different Electrical Conductivity Values in a Simplified Recirculating Soilless System on Inner and Outer Fruit Quality Characteristics of Tomato. J. Agric. Food Chem. 2006, 54, 441-448. [CrossRef] 
39. Lorito, M.; Woo, S. Trichoderma: A Multi-Purpose Tool for Integrated Pest Management. In Principles of Plant-Microbe Interactions; Lugtenberg, B., Ed.; Springer International Publishing: Cham, Switzerland, 2015; pp. 345-353. [CrossRef]

40. Li, R.-X.; Cai, F.; Pang, G.; Shen, Q.-R.; Li, R.; Chen, W. Solubilisation of phosphate and micronutrients by Trichoderma harzianum and its relationship with the promotion of tomato plant growth. PLoS ONE 2015, 10, e0130081. [CrossRef]

41. Contreras-Cornejo, H.A.; Macías-Rodríguez, L.; Cortés-Penagos, C.; López-Bucio, J. Trichoderma virens, a plant beneficial fungus, enhances biomass production and promotes lateral root growth through an auxin-pependent mechanism in Arabidopsis. Plant Physiol. 2009, 149, 1579-1592. [CrossRef]

42. Chacón, M.; Rodríguez-Galán, O.; Benítez, T.; Sousa, S.; Rey, M.; Llobell, A.; Delgado-Jarana, J. Microscopic and transcriptome analyses of early colonization of tomato roots by Trichoderma harzianum. Int. Microbiol. Off. J. Span. Soc. Microbiol. 2007, 10, 19-27. [CrossRef]

43. Davidson, D.; Verma, M.; Gu, F. Controlled root targeted delivery of fertilizer using an ionically crosslinked carboxymethyl cellulose hydrogel matrix. SpringerPlus 2013, 2, 318. [CrossRef]

44. Ye, X.; Chen, X.-F.; Deng, C.-L.; Yang, L.-T.; Lai, N.-W.; Guo, J.-X.; Chen, L.-S. Magnesium-deficiency effects on pigments, photosynthesis and photosynthetic electron transport of leaves, and nutrients of leaf blades and veins in Citrus sinensis seedlings. Plants 2019, 8, 389. [CrossRef]

45. Lubitz, W.; Chrysina, M.; Cox, N. Water oxidation in photosystem II. Photosynth. Res. 2019, 142, $105-125$. [CrossRef] [PubMed]

46. Singh, B.N.; Dwivedi, P.; Sarma, B.K.; Singh, G.S.; Singh, H.B. Trichoderma asperellum T42 reprograms tobacco for enhanced nitrogen utilization efficiency and plant growth when fed with N nutrients. Front. Plant Sci. 2018, 9. [CrossRef] [PubMed]

47. Domínguez, S.; Rubio, M.B.; Cardoza, R.E.; Gutiérrez, S.; Nicolás, C.; Bettiol, W.; Hermosa, R.; Monte, E. Nitrogen metabolism and growth enhancement in tomato plants challenged with Trichoderma harzianum expressing the Aspergillus nidulans Acetamidase amd S gene. Front. Microbiol. 2016, 7, 1182. [CrossRef] [PubMed]

48. Woodrow, P.; Ciarmiello, L.; Annunziata, M.G.; Pacifico, S.; Iannuzzi, F.; Mirto, A.; D’Amelia, L.; Dell'Aversana, E.; Piccolella, S.; Fuggi, A.; et al. Durum wheat seedling responses to simultaneous high light and salinity involve a fine reconfiguration of amino acids and carbohydrate metabolism. Physiol. Plant. 2017, 159, 290-312. [CrossRef] [PubMed]

49. Annunziata, M.G.; Ciarmiello, L.F.; Woodrow, P.; Dell'Aversana, E.; Carillo, P. Spatial and temporal profile of glycine betaine accumulation in plants under abiotic stresses. Front. Plant Sci. 2019, 10, 230. [CrossRef] [PubMed]

50. Carillo, P. GABA Shunt in Durum Wheat. Front. Plant Sci. 2018, 9. [CrossRef]

51. Ramos-Ruiz, R.; Poirot, E.; Flores-Mosquera, M. GABA, a non-protein amino acid ubiquitous in food matrices. Cogent Food Agric. 2018, 4, 1534323. [CrossRef]

52. Ngo, D.-H.; Vo, T.S. An Updated review on pharmaceutical properties of gamma-aminobutyric acid. Molecules 2019, 24, 2678. [CrossRef]

53. Tiansawang, K.; Luangpituksa, P.; Varanyanond, W.; Hansawasdi, C. GABA ( $\gamma$-aminobutyric acid) production, antioxidant activity in some germinated dietary seeds and the effect of cooking on their GABA content. Food Sci. Technol. (Camp.) 2016, 36. [CrossRef]

54. Carillo, P.; Kyriacou, M.C.; El-Nakhel, C.; Pannico, A.; dell'Aversana, E.; D’Amelia, L.; Colla, G.; Caruso, G.; De Pascale, S.; Rouphael, Y. Sensory and functional quality characterization of protected designation of origin 'Piennolo del Vesuvio' cherry tomato landraces from Campania-Italy. Food Chem. 2019, 292, 166-175. [CrossRef]

55. Shahidi, F.; Ambigaipalan, P. Phenolics and polyphenolics in foods, beverages and spices: Antioxidant activity and health effects-A review. J. Funct. Foods 2015, 18. [CrossRef]

56. Caruso, G.; El-Nakhel, C.; Rouphael, Y.; Comite, E.; Lombardi, N.; Cuciniello, A.; Woo, S.L. Diplotaxis tenuifolia (L.) DC. yield and quality as influenced by cropping season, protein hydrolysates, and Trichoderma applications. Plants 2020, 9, 697. [CrossRef] [PubMed]

57. Kim, M.J.; Kim, H. Anticancer effect of lycopene in gastric carcinogenesis. J. Cancer Prev. 2015, 20, 92-96. [CrossRef] 
58. Thies, F.; Mills, L.M.; Moir, S.; Masson, L.F. Cardiovascular benefits of lycopene: Fantasy or reality? Proc. Nutr. Soc. 2016, 76, 122-129. [CrossRef] [PubMed]

59. Subhash, K.; Bose, C.; Agrawal, B.K. Effect of short term supplementation of tomatoes on antioxidant enzymes and lipid peroxidation in type-II diabetes. Indian J. Clin. Biochem. 2007, 22, 95-98. [CrossRef]

60. Frusciante, L.; Carli, P.; Ercolano, M.R.; Pernice, R.; Di Matteo, A.; Fogliano, V.; Pellegrini, N. Antioxidant nutritional quality of tomato. Mol. Nutr. Food Res. 2007, 51, 609-617. [CrossRef]

61. Sipos, L.; Orbán, C.; Bálint, I.; Csambalik, L.; Divéky-Ertsey, A.; Gere, A. Colour parameters as indicators of lycopene and antioxidant activity traits of cherry tomatoes (Solanum lycopersicum L.). Eur. Food Res. Technol. 2017, 243, 1533-1543. [CrossRef]

62. Singleton, V.L.; Orthofer, R.; Lamuela-Raventós, R.M. Analysis of total phenols and other oxidation substrates and antioxidants by means of folin-ciocalteu reagent. Methods Enzymol. 1999, 299, 152-178.

63. Carillo, P.; Colla, G.; El-Nakhel, C.; Bonini, P.; D'Amelia, L.; Dell'Aversana, E.; Pannico, A.; Giordano, M.; Sifola, M.I.; Kyriacou, M.C.; et al. Biostimulant application with a tropical plant extract enhances Corchorus olitorius adaptation to sub-optimal nutrient regimens by improving physiological parameters. Agronomy 2019, 9, 249. [CrossRef]

64. Sadler, G.; Davis, J.; Dezman, D. Rapid Extraction of lycopene and $\beta$-Carotene from reconstituted tomato paste and pink grapefruit homogenates. J. Food Sci. 1990, 55, 1460-1461. [CrossRef]

65. Ciarmiello, L.; Piccirillo, P.; Carillo, P.; Luca, A.; Woodrow, P. Determination of the genetic relatedness of fig (Ficus carica L.) accessions using RAPD fingerprint and their agro-morphological characterization. S. Afr. J. Bot. 2015. [CrossRef]

(C) 2020 by the authors. Licensee MDPI, Basel, Switzerland. This article is an open access article distributed under the terms and conditions of the Creative Commons Attribution (CC BY) license (http://creativecommons.org/licenses/by/4.0/). 